\begin{tabular}{|c|c|}
\hline 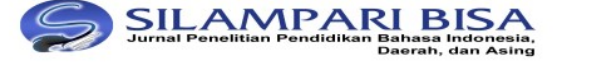 & $\begin{array}{r}\text { PRINTED ISSN: } 2620-6919 \\
\text { ONLINE ISSN: } 2620-3316\end{array}$ \\
\hline $\begin{array}{l}\text { Published by LP4MK STKIP PGRI LUBUKLINGGAU } \\
\text { Prodi Pendidikan Bahasa Indonesia, STKIP PGRI Lubuklinggau, } \\
\text { South Sumatera, Indonesia }\end{array}$ & $\begin{array}{c}\text { Vol. 4, No. 2, } 2021 \\
\text { Page: } 267-278\end{array}$ \\
\hline
\end{tabular}

\title{
Peningkatan Kemampuan Menulis melalui Media Gambar Berseri dalam Pembelajaran Bahasa Inggris pada Siswa Kelas VIII SMPN Kelapa 2 Kabupaten Tangerang
}

\author{
Netty Rismayanti \\ SMPN Kelapa 2 Kabupaten Tangerang \\ Email: nettyrismayanti774@gmail.com
}

\begin{abstract}
APA Citation: Rismayanti, N. (2021). Peningkatan Kemampuan Menulis melalui Media Gambar Berseri dalam Pembelajaran Bahasa Inggris pada Siswa Kelas VIII SMPN Kelapa 2 Kabupaten Tangerang. Silampari Bisa: Jurnal Penelitian Pendidikan Bahasa Indonesia, Daerah, dan Asing, 4(2), 267-278. https://doi.org/10.31540/silamparibisa.v4i2.1362
\end{abstract}

\begin{abstract}
Abstrak
Penelitian tindakan kelas ini bertujuan untuk meningkatkan kemampuan menulis melalui media gambar berseri dalam pembelajaran bahasa Inggris pada siswa kelas VIII SMPN Kelapa 2 Kabupaten Tangerang. Penelitian ini dilaksanakan pada siswa kelas VIII yang berjumlah 35 siswa yang terdiri dari 15 siswa laki-laki dan 20 siswa perempuan. Metode penelitian yang digunakan pada penelitian ini adalah penelitian tindakan kelas dengan menggunakan model spiral dari Kemmis dan Mc Taggart. Adapun tahap-tahap penelitian tindakan kelas menurut Kemmis dan Mc Taggart yaitu perencanaan, tindakan, pengamatan, dan refleksi. Peningkatan nilai tes menulis dari kondisi awal ke siklus I hingga siklus III yaitu nilai rata-rata pada kondisi awal 59,67 dengan presentase ketuntasan $43,33 \%$ (18 orang), pada siklus I meningkat menjadi 65,33 dengan persentase ketuntasan $60 \%$ ( 23 orang), pada siklus II meningkat menjadi 72 dengan presentase ketuntasan $73,33 \%$ ( 27 orang), dan pada siklus III meningkat menjadi 75,66 dengan persentase ketuntasan $86,66 \%$ (31 orang). Hasil yang diperoleh dari penelitian tindakan kelas terhadap 35 siswa yaitu dengan meningkatnya nilai rata-rata dari kondisi awal sebesar 59,67 meningkat menjadi 65,33 pada siklus I, pada siklus II meningkat menjadi 72 dan pada siklus III meningkat menjadi 75,66. Hal ini dapat disimpulkan bahwa media gambar berseri pada pembelajaran bahasa Inggris dapat meningkatkan kemampuan menulis siswa kelas VIII SMPN Kelapa 2 Kabupaten Tangerang. Para guru bahasa Inggris diharapkan menggunakan dan menerapkan media gambar berseri dalam pelaksanaan pembelajaran Bahasa Inggris pada materi menulis di kelas. Guru bahasa Inggris dapat menggunakan media gambar berseri sebagai media pembelajaran yang dapat meningkatkan kemampuan menulis siswa, agar siswa dapat dengan mudah mengembangkan ide atau pikirannya dalam menulis.
\end{abstract}

Kata kunci: peningkatan, kemampuan menulis, media gambar berseri, pembelajaran bahasa Inggris 


\title{
Netty Rismayanti
}

Peningkatan Kemampuan Menulis melalui Media Gambar Berseri dalam Pembelajaran Bahasa Inggris pada Siswa Kelas VIII SMPN Kelapa 2 Kabupaten Tangerang

\section{Improving Writing Ability through Picture Series Media in Learning English for Class VIII Students of SMPN Kelapa 2 Tangerang Regency}

\begin{abstract}
This classroom action research aims to improve writing skills through picture series media in learning English in class VIII students of SMPN Kelapa 2 Tangerang Regency. This research was carried out on class VIII students, totaling 35 students consisting of 15 male students and 20 female students. The research method used in this research is classroom action research using the spiral model of Kemmis and Mc Taggart. The stages of classroom action research according to Kemmis and Mc Taggart are planning, action, observation, and reflection. The increase in the writing test scores from the initial conditions to the first cycle to the third cycle, namely the average value in the initial conditions was 59.67 with a percentage of completeness $43.33 \%$ (18 people), in the first cycle increased to 65.33 with a percentage of completeness $60 \%$ ( 23 people), in the second cycle it increased to 72 with a completeness percentage of $73.33 \%$ (27 people), and in the third cycle it increased to 75.66 with a completeness percentage of $86.66 \%$ (31 people). The results obtained from classroom action research on 35 students, namely by increasing the average value from the initial conditions of 59.67, increasing to 65.33 in the first cycle, in the second cycle increasing to 72 and in the third cycle increasing to 75.66 . It can be concluded that picture series media in learning English can improve the writing ability of class VIII students of SMPN Kelapa 2 Tangerang Regency. English teachers are expected to use and apply picture series media in the implementation of English learning on writing material in class. English teachers can use picture series media as learning media that can improve students' writing skills, so that students can easily develop their ideas or thoughts in writing.
\end{abstract}

Keywords: improvement, writing skills, picture series media, learning English

\section{A. Pendahuluan}

Bahasa adalah alat komunikasi seseorang yang berupa bunyi dan mempunyai makna (Brown, 2020). Dengan bahasa seseorang dapat mengungkapkan pikiran dan perasaannya, serta dapat berinteraksi dengan sesama makhluk hidup. Jadi, dapat disimpulkan karakteristik pembelajaran bahasa adalah mengajarkan anak terampil dalam menyimak, membaca, menulis, dan berbicara (Tarigan, 2015). Pembelajaran bahasa berfungsi untuk meningkatkan kemampuan peserta didik dalam berkomunikasi (Widodo, 2021). Komunikasi tersebut tentunya dengan menggunakan bahasa yang baik dan benar, baik secara lisan maupun tulisan, serta menumbuhkan apresiasi terhadap hasil karya sastra Indonesia. Agar dapat berkomunikasi dengan baik, seseorang perlu belajar cara berbahasa yang baik dan benar. Cara tersebut akan lebih baik jika diajarkan sejak dini dan berkesinambungan.

Setiap keterampilan berhubungan dengan keterampilan yang beraneka ragam, keterampilan berbahasa biasanya melalui urutan yang teratur, mula-mula pada masa kecil kita akan belajar menyimak bahasa kemudian berbicara, lalu setelah itu kita belajar membaca dan menulis (Dardjowidjojo, 2014). Keterampilan menyimak dan berbicara lalu yang dipelajari menyimak dan berbicara yang dipelajari sebelum sebelum memasuki masa sekolah. Dari keempat keterampilan tersebut yang pada dasarnya merupakan memiliki hubungan yang erat karena melalui keterampilan yang pertama tentunya akan menghasilkan keterampilan-keterampilan yang lebih banyak lagi.

Silampari Bisa: Jurnal Penelitian Pendidikan Bahasa Indonesia, Daerah, dan Asing Vol. 4, No. 2, 2021 


\section{Netty Rismayanti}

Peningkatan Kemampuan Menulis melalui Media Gambar Berseri dalam Pembelajaran Bahasa Inggris pada Siswa Kelas VIII SMPN Kelapa 2 Kabupaten Tangerang

Menurut Jauhari (2013:16), menulis merupakan salah satu aspek keterampilan berbahasa ketiga setelah menyimak dan berbicara, kemudian membaca. Keterampilan menulis ialah keterampilan proses karena hampir semua orang yang membuat tulisan, baik karya ilmiah, non ilmiah, maupun hanya catatan pribadi, jarang yang melakukannya secara spontan dan langsung jadi. Membuat tulisan sederhana pun pasti ada perencanaan dan perbaikan (revisi dan mengeditan) paling tidak dibaca lagi sebelum dianggap jadi.

Menurut Tarigan (2008:3), menulis merupakan suatu keterampilan berbahasa yang dipergunakan untuk berkomunikasi secara tidak langsung, tidak secara tatap muka dengan orang lain. Menulis merupakan suatu kegiatan yang produktif dan ekspresif. Dalam kegiatan menulis ini, penulis haruslah terampil memanfaatkan grafolegi, setruktur bahasa, dan kosa kata. Menurut Nurdin (2010:35), menulis merupakan suatu kegiatan yang produktif dan ekspresif dalam kegiatan menulis ini seorang penulis haruslah terampil, keterampilan menulis merupakan suatu ciri dari orang yang terpelajar (Sulaeman \& Ariyana, 2018). Menulis adalah kegiatan yang dilakukan seseorang untuk dapat menghasilkan tulisan yang dipergunakan untuk melaporkan atau memberitahukan dan mempengaruhi dan tujuan seperti itu dapat dilakukan dengan mengutarakan pikiran dengan jelas, atau kejelasan yang dipakai untuk memilih kata-kata dan struktur kalimat yang tepat. Adapun unsur-unsur menulis sebagai berikut.

1. Gagasan merupakan suatu pendapat, pengalaman, ataupun pengetahuan yang ada dalam pikiran seseorang. Gagasan seorang akan sangat tegantung pada pengalaman pada masa lalu dari pengetahuan yang dimilikinya.

2. Tuturan adalah pengungkapan gagasan sehingga bisa dipahami oleh pembaca ada bermacam-macam tuturan antara lain: narasi (pencitraan), deskripsi (pelukisan), eksposisi (pengungkapan berdasarkan fakta secara teratur logis dan terpadu), argumentasi (meyakinkan), dan persuasi (pembujukan).

3. Tatanan di sini merupakan tertib pengaturan dan penyusunan gagasan dengan mengindahkan berbagai asas, aturan, dan teknik karenanya menulis disertai dengan sebuah "aturan".

4. Wahana bisa disebut dengan alat wahana dalam menulis berarti sasaran yang mengantar gagasan yang berupa bahasa tulis yang terutama menyangkut kosakata, gramatika, dan retorika (seni memakai bahasa) bagi seorang penulis pemula wahana sering menjadi masalah yang krusial, tetapi jika disertai dengan niat dan terus belajar menulis, wahana lambat laun akan bisa dilalui dengan mudah.

Jadi, memiliki keterampilan menulis sangat penting bagi pendidik karena dapat membantu dan memudahkan para pelajar berpikir secara kritis juga dapat memudahkan kita dalam merasakan dan menikmati hubungan-hubungan, memperdalam daya tanggap atau presepsi kita.

Dalam proses pembelajaran menulis dibutuhkan kehadiran media gambar agar siswa terbantu dalam menuangkan idenya ke dalam bentuk karangan (Oktovan dkk., 2020). Dengan demikian, anak didik lebih mudah mencerna bahan daripada tanpa bantuan media. Kata media berasal dari bahasa latin dan merupakan bentuk jamak dari kata medium, yang secara harfiah berarti perantara atau pengantar. Dengan demikian, Media merupakan wahana penyalur informasi belajar atau penyalur pesan (Djamarah \& Zain, 2010:120). Media juga berupakan beberapa bentuk komunikasi, baik tercetak maupun audiovisual serta peralatannya (Sadiman dkk., 2010:7; Arsyad,

Silampari Bisa: Jurnal Penelitian Pendidikan Bahasa Indonesia, Daerah, dan Asing Vol. 4, No. 2, 2021 


\section{Netty Rismayanti}

Peningkatan Kemampuan Menulis melalui Media Gambar Berseri dalam Pembelajaran Bahasa Inggris pada Siswa Kelas VIII SMPN Kelapa 2 Kabupaten Tangerang

2011:3). Dari dua pendapat di atas dapat disimpulkan bahwa media adalah bentuk perantara informasi belajar, baik tercetak maupun audiovisual sebagai penyalur pesan.

Dengan adanya media terutama media gambar berseri diharapkan siswa terbantu dalam menuangkan ide awal dalam menulis karangan dalam pembelajaran bahasa Inggris di Kelas VIII SMPN Kelapa 2 Kabupaten Tangerang. Dengan adanya ide awal para siswa lebih mudah mengembangkan tulisannya menjadi karangan yang menarik. Dengan melihat gambar, siswa dapat menarik isi kesimpulan dari gambar tersebut, kemudian dapat menguraikan dalam bentuk tulisan.

Penggunaan media gambar berseri sangat tepat untuk membantu siswa dalam keterampilan mengarang. Gambar berseri atau bersambung merupakan media grafis yang digunakan untuk menerangkan suatu rangkaian perkembangan, sebab setiap seri media gambar bersambung dan selalu terdiri dari sejumlah gambar (Sarudi, 2018; Rohami, 1997:13). Kata dasar "berseri" adalah "seri" yang berarti sesuatu secara berturut-turut dari suatu bagian ke bagian lain. Gambar berseri berarti gambar yang berurutan dari salah satu jenis ke jenis lainnya, dari salah satu kegiatan menuju kegiatan lain. Helda (2017) dan Khaerunisa (2012) menjelaskan bahwa penggunaan smedia gambar berseri selain dapat memudahkan, memperjelas, mengatasi keterbatasan daya indra, mengatasi sikap pasif siswa, juga mampu memberikan bantuan dalam siswa menuangkan ide awal ketika menulis. Untuk itu, dalam penelitian ini akan dilaksanakan penelitian tindakan kelas dengan rumusan masalah "Bagaimanakah peningkatan kemampuan menulis melalui media gambar berseri dalam pembelajaran bahasa inggris pada Siswa Kelas VIII SMPN Kelapa 2 Kabupaten Tangerang? Dengan tujuan mendeskripsikan peningkatan kemampuan menulis melalui media gambar berseri dalam pembelajaran bahasa inggris pada siswa Kelas VIII SMPN Kelapa 2 Kabupaten Tangerang baik dari segi keakifan siswa dan hasil belajar siswa dalam menulis karangan dalam bahasa Inggris.

\section{B. Metode Penelitian}

1. Desain dan Model Penelitian

Dalam penelitian ini pendekatan yang digunakan adalah pendekatan campuran dengan menggunakan metode penelitian tindakan kelas (classroom action research). Menurut Sulaeman (2019:57), penelitian tindakan kelas atau PTK merupakan penelitian yang dilakukan oleh guru sendiri yang juga bertindak sebagai peneliti di kelas atau di sekolah tempat ia mengajar dengan penekanan pada penyempurnaan atau peningkatan proses dan praktis pembelajaran.

Penelitian tindakan kelas yang dilakukan bertujuan memperbaiki mutu praktik pembelajaran di kelas. Penelitian tindakan kelas berfokus pada kelas atau pada proses belajar-mengajar yang terjadi di kelas, bukan pada input kelas (silabus, materi, dan lain-lain) ataupun output (hasil belajar).

Desain penelitian tindakan kelas yang digunakan yaitu PTK partisipan yang mana peneliti adalah guru yang melakukan tindakan. Kusumah \& Dwitagama (2010:11) mengemukakan dalam penelitian tindakan kelas, guru harus bertindak sebagai pengajar sekaligus peneliti. Guru merupakan orang yang paling akrab dengan kelasnya dan biasanya interaksi yang terjadi antara guru dan siswa berlangsung unik. Guru pun mempunyai hak otonomi untuk menilai sendiri kinerjanya. Metode yang

Silampari Bisa: Jurnal Penelitian Pendidikan Bahasa Indonesia, Daerah, dan Asing Vol. 4, No. 2, 2021 


\section{Netty Rismayanti}

Peningkatan Kemampuan Menulis melalui Media Gambar Berseri dalam Pembelajaran Bahasa Inggris pada Siswa Kelas VIII SMPN Kelapa 2 Kabupaten Tangerang

paling utama adalah merefleksikan diri dengan tetap mengikuti kaidah-kaidah penelitian yang sudah baku dan bukan tradisional.

Jadi dalam hal ini guru bukan hanya mengajarkan saja, tetapi sekaligus meneliti keadaan kelas dalam kegiatan belajar mengajar, agar pembelajaran dapat berlangsung dengan baik. Dengan begitu guru dituntut untuk dapat menguasai kelas agar bisa berinteraksi dengan siswanya. Dalam hal ini, peneliti berperan sebagai pengajar, perencana, pelaksanaan tindakan dan refleksi, mengumpulkan dan menganalisis data, melaporkan hasil penelitian, serta melibatkan dua orang guru bidang studi sebagai observer dan siswa dalam melaksanakan penelitian tindakan kelas.

Model penelitian tindakan kelas yang digunakan peneliti yaitu model Kemmis dan Mc Taggart. Adapun tahap-tahap penelitian tindakan kelas menurut Kemmis dan Mc Taggart adalah sebagai berikut: "Konsep pokok penelitian tindakan kelas terdiri dari empat komponen, yaitu perencanaan (planning), tindakan (acting), pengamatan (observing), dan refleksi (reflecting)" (Kusumah \& Dwitagama, 2010:20). Hanya saja pada komponen acting dan observing dijadikan sebagai satu kesatuan, karena antara penerapan acting dan observing merupakan dua kegiatan yang tidak terpisahkan. Maksudnya, dua kegiatan harus dilakukan dalam satu kesatuan waktu, ketika tindakan dilaksanakan begitu pula pengamatan juga harus dilaksanakan. Hubungan keempat komponen tersebut dapat digambarkan sebagai berikut:

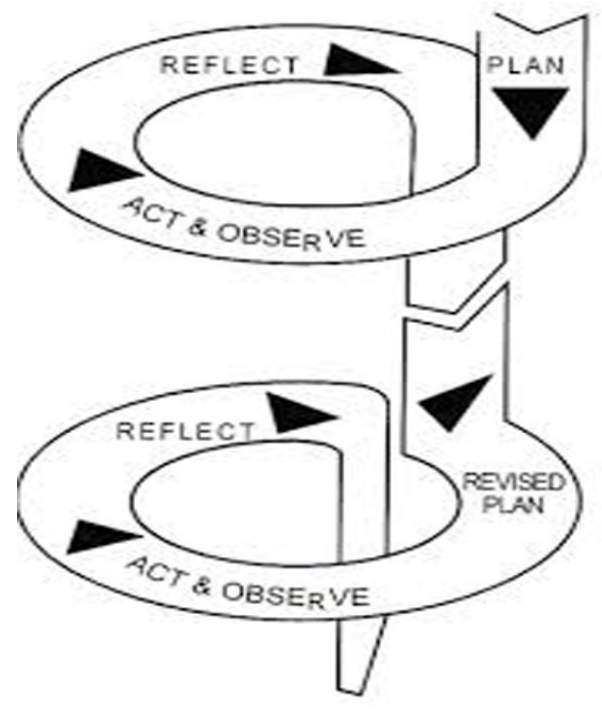

Gambar1. Penelitian Model Spiral atau Siklus dari Kemmis dan Mc Taggart

(Sumber: Kusumah \& Dwitagama, 2010:21)

Model ini pada hakikatnya berupa perangkat-perangkat atau untaian-untaian dengan satu perangkat, keempat komponen yang berupa untaian tersebut dipandang sebagai satu siklus. Kusumah \& Dwitagama (2010:21) menyatakan bahwa "Pengertian siklus adalah putaran kegiatan yang terdiri dari perencanaan, tindakan, pengamatan, dan refleksi. Pada gambar di atas tampak bahwa di dalamnya terdiri dari dua perangkat komponen yang dapat dikatakan sebagai dua siklus. Untuk pelaksanaan sesungguhnya, jumlah siklus sangat bergantung kepada permasalahan 


\section{Netty Rismayanti}

Peningkatan Kemampuan Menulis melalui Media Gambar Berseri dalam Pembelajaran Bahasa Inggris pada Siswa Kelas VIII SMPN Kelapa 2 Kabupaten Tangerang

yang perlu diselesaikan, akan tetapi untuk penelitian ini minimalnya akan dilaksanakan tiga siklus.

\section{Tempat Penelitian}

Penelitian ini dilakukan di kelas VIII SMPN Kelapa 2 Kabupaten Tangerang. Peneliti mempunyai alasan dalam memilih tempat penelitian di sekolah tersebut karena siswa kelas VIII dalam hal menulis sulit untuk mengungkapkan ide/pikiran ke dalam bentuk tulisan. Dalam hal ini siswa masih perlu dibimbing dan diperlukan juga media yang dapat membantu atau mempermudah kelangsungan kegiatan belajar mengajar. Maka dari itu peneliti menggunakan media gambar berseri untuk mempermudah siswa dalam pembelajaran bahasa Inggris materi menulis, sekaligus peneliti juga termasuk guru di sekolah tersebut.

\section{Teknik Pengumpulan Data}

Teknik pengumpulan data dalam penelitian ini yaitu teknik observasi, tes, dan dokumentasi. Untuk itu, uji keabsahan data menggunakan triangulasi sumber data. Instrumen penelitian yaitu lembar observasi proses pembelajaran menulis, tes unjuk kerja menulis, dan handycam. Dalam penelitian observasi dilakukan oleh teman sejawat selama guru melaksanakan pembelajaran menulis pada pembelajaran bahasa Inggris dengan menggunakan media gambar berseri di SMPN Kelapa 2 Kabupaten Tangerang. Kemudian, tes unjuk kerja berupa kegiatan menulis karangan dalam bahasa Inggris dengan bantuan gambar berseri.

\section{Teknik Analisis Data}

Langkah-langkah analisis data penelitian tindakan kelas yaitu dimulai dengan menganalisis data kualitatif dari hasil observasi, dilanjutkan menganalisis data kuantitatif yaitu hasil tes menulis karangan dalam bahasa Inggris siswa, dan membuat kesimpulan tentang capaian keberhasilan PTK sesuai indikator keberhasilan yang sudah ditetapkan oleh peneliti yaitu terjadi peningkatan nilai rata-rata pada setiap siklus dan terjadi peningkatan keaktifan siswa dari setiap siklus.

\section{Hasil Penelitian dan pembahasan}

\section{Hasil Penelitian}

\section{a. Hasil Penelitian Siklus Pertama}

Pada siklus I dirancang pembelajaran menulis karangan dengan menggunakan media gambar berseri, yang merupakan media pembelajaran yang membuat anak lebih tertarik dalam belajar. Waktu yang digunakan untuk pembelajaran disesuaikan dengan jadwal yang telah ada yaitu 2 kali pertemuan dalam 1 kali pertemuan membutuhkan waktu 2 × 35 menit. Berikut data nilai siswa pada siklus I.

Tabel 1. Nilai Siswa Kondisi Awal dan Siklus I

\begin{tabular}{ccccccc}
\hline $\begin{array}{c}\text { Jumlah } \\
\text { Siswa }\end{array}$ & $\begin{array}{c}\text { Nilai } \\
\text { Maksimum }\end{array}$ & $\begin{array}{c}\text { Nilai } \\
\text { Minimum }\end{array}$ & Rata-Rata & $\begin{array}{c}\text { Nilai } \\
\text { KKM }\end{array}$ & $\begin{array}{c}\text { Persentase } \\
\text { Ketuntasan }\end{array}$ & Keterangan \\
\hline 35 & 70 & 40 & 59,67 & 70 & $43,33 \%$ & Kondisi Awal \\
\hline 35 & 90 & 40 & 65,33 & 70 & $60 \%$ & Siklus I \\
\hline
\end{tabular}

Berdasarkan tabel 1 di atas, dari hasil tes menulis menggunakan media gambar berseri pada siklus I, nilai maksimum yang dicapai yaitu 90 dan nilai minimum yang 


\section{Netty Rismayanti}

Peningkatan Kemampuan Menulis melalui Media Gambar Berseri dalam Pembelajaran Bahasa Inggris pada Siswa Kelas VIII SMPN Kelapa 2 Kabupaten Tangerang

dicapai yaitu 40 . Nilai rata-ratanya yaitu 65,33 dengan persentase ketuntasan $60 \%$ (28 orang).

Perolehan dari hasil tes menulis menggunakan media gambar berseri pada siklus I digambarkan dengan diagram berikut.

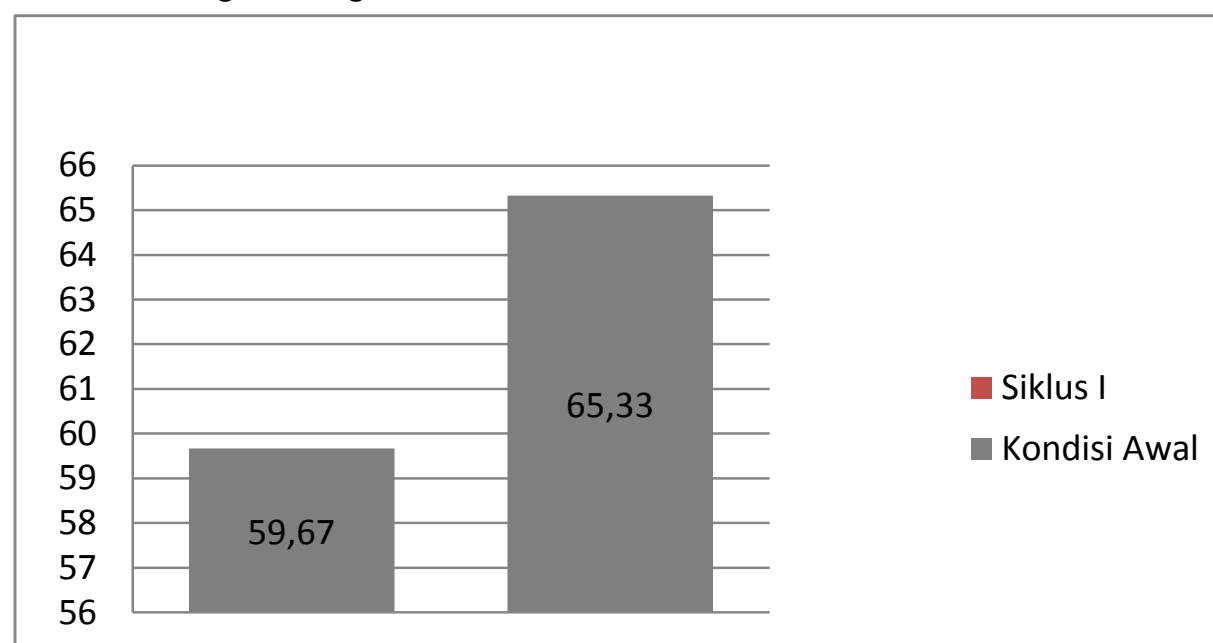

Gamb̈ar 2. Diagram Perbandingan Hasil Tes Menulis Siklus I dengan Kondisi Awal

Berdasarkan diagram hasil tes menulis siklus I di atas, terlihat bahwa adanya proses suatu peningkatan hasil tes menulis siswa tetapi hasilnya belum maksimal, nilai rata-rata pada kondisi awal 59,67 dan terjadi peningkatan di siklus I dengan nilai rata-rata 65,33 .

\section{b. Hasil Penelitian Siklus Kedua}

Perolehan dari hasil tes menulis menggunakan media gambar berseri pada siklus II digambarkan dengan diagram berikut.

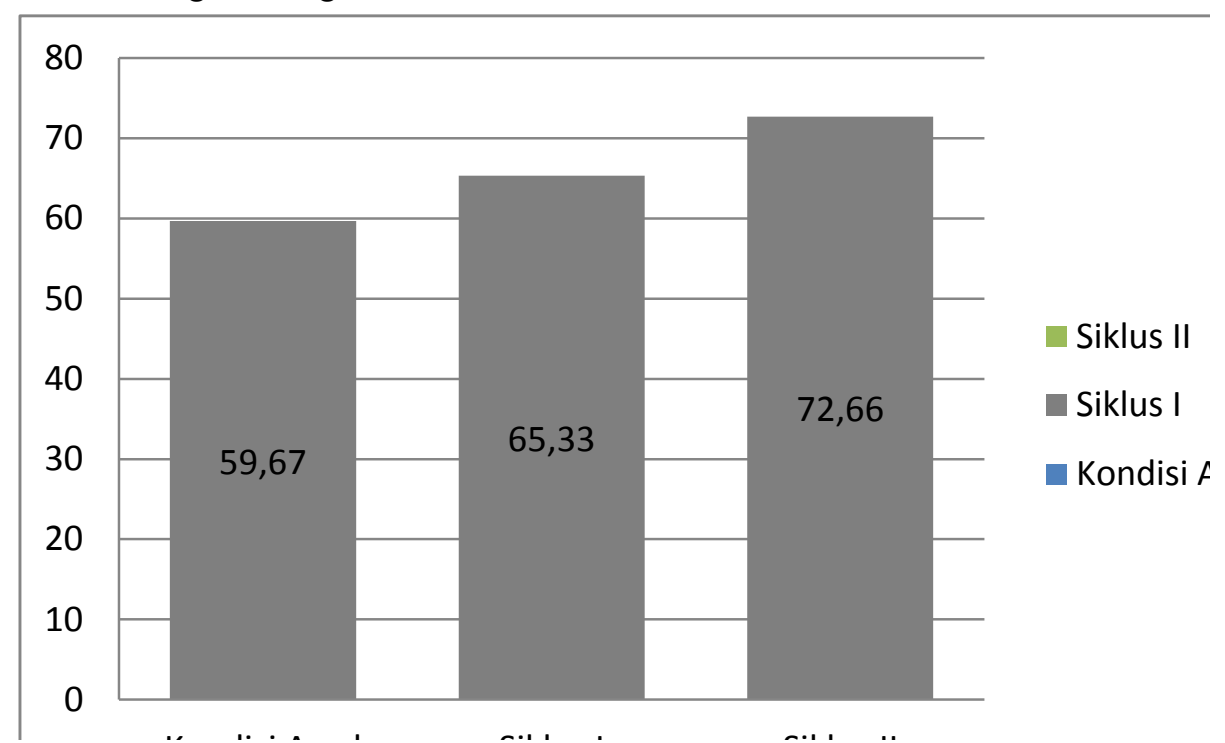

Gambar 3. Diagram Hasil Tes Menulis Siklus III' dän Perbandingannya dengan Hasil Tes Awal, dan Siklus I

Silampari Bisa: Jurnal Penelitian Pendidikan Bahasa Indonesia, Daerah, dan Asing Vol. 4, No. 2, 2021 


\section{Netty Rismayanti}

Peningkatan Kemampuan Menulis melalui Media Gambar Berseri dalam Pembelajaran Bahasa Inggris pada Siswa Kelas VIII SMPN Kelapa 2 Kabupaten Tangerang

Berdasarkan diagram hasil tes meulis siklus II di atas, terlihat bahwa adanya proses suatu peningkatan hasil tes menulis siswa pada setiap siklusnya yaitu kondisi awal 59,67, pada siklus I meningkat menjadi 65,33 dan pada siklus II meningkat menjadi 72,66 .

\section{c. Hasil Penelitian Siklus Ketiga}

Setelah dilakukan perencanaan, tindakan, pengamatan, peneliti bersama observer mengadakan refleksi tindakan-tindakan yang telah dilakukan pada siklus I dan siklus II, dan hasilnya masih belum maksimal untuk menyempurnakan hasil dari penelitian diadakan siklus III. Pelaksanaan siklus III yaitu dilakukan sebanyak 2 kali pertemuan.

Pelaksanaan penelitian pada siklus III yang dilakukan dalam dua kali pertemuan, dengan hasil menulis menggunakan media gambar berseri adalah sebagai berikut.

Tabel 2. Nilai Siswa Kondisi Awal, Siklus I, Siklus II, dan Siklus III

\begin{tabular}{ccccccc}
\hline $\begin{array}{c}\text { Jumlah } \\
\text { Siswa }\end{array}$ & $\begin{array}{c}\text { Nilai } \\
\text { Maksimum }\end{array}$ & $\begin{array}{c}\text { Nilai } \\
\text { Minimum }\end{array}$ & Rata-rata & $\begin{array}{c}\text { Nilai } \\
\text { KKM }\end{array}$ & $\begin{array}{c}\text { Persentase } \\
\text { Ketuntasan }\end{array}$ & Keterangan \\
\hline 35 & 70 & 40 & 59,67 & 70 & $43,33 \%$ & Kondisi Awal \\
\hline 35 & 90 & 40 & 65,33 & 70 & $60 \%$ & Siklus I \\
\hline 35 & 90 & 50 & 72 & 70 & $73,33 \%$ & Siklus II \\
\hline 35 & 90 & 55 & 75,66 & 70 & $86,66 \%$ & Siklus III \\
\hline
\end{tabular}

Berdasarkan tabel 4.4 di atas, dari hasil tes menulis menggunakan media gambar berseri pada siklus III nilai maksimum yang dicapai yaitu 90 dan nilai minimum yang dicapai yaitu 55. Nilai rata-ratanya yaitu 75,66 dengan persentase ketuntasan $86,66 \%$ (26 siswa).

Perolehan dari hasil tes menulis menggunakan media gambar berseri pada siklus III digambarkan dengan diagram berikut.

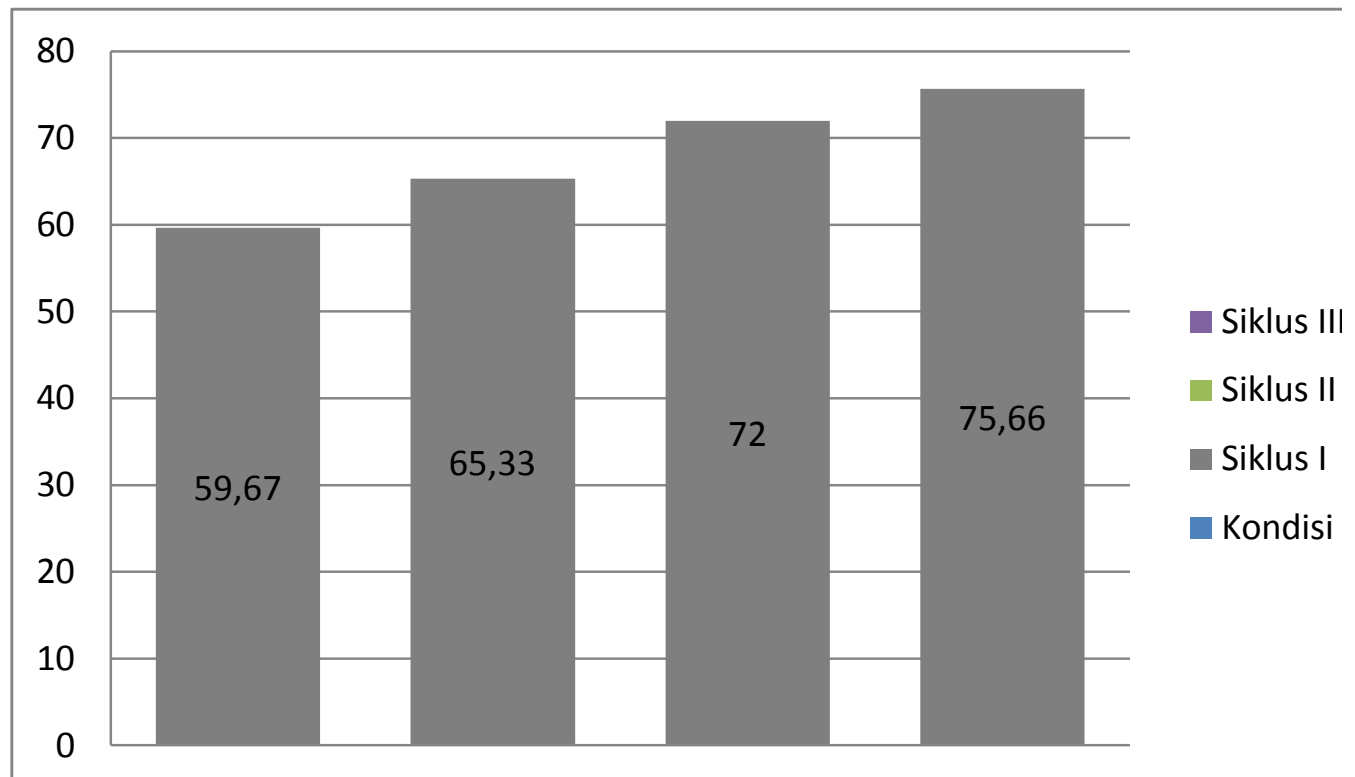

Gambar 4. Diagram Hasil Tes Menulis Siklus III

Silampari Bisa: Jurnal Penelitian Pendidikan Bahasa Indonesia, Daerah, dan Asing Vol. 4, No. 2, 2021 
Netty Rismayanti

Peningkatan Kemampuan Menulis melalui Media Gambar Berseri dalam Pembelajaran Bahasa Inggris pada Siswa Kelas VIII SMPN Kelapa 2 Kabupaten Tangerang

Berdasarkan diagram hasil tes menulis siklus III di atas, terlihat bahwa adanya proses suatu peningkatan hasil tes mengarang siswa pada setiap siklusnya yaitu kondisi awal 59,67, pada siklus I meningkat menjadi 65,33, pada siklus II meningkat menjadi 72 , dan pada siklus III meningkat menjadi 75,66.

\section{Pembahasan}

Secara umum proses pembelajaran bahasa Inggris pada materi menulis karangan dengan menerapkan media gambar berseri pada Siswa Kelas VIII SMPN Kelapa 2 Kabupaten Tangerang yang berlangsung di setiap siklus sudah berjalan dengan baik. Semua tahapan yang terdapat dalam pembelajaran menggunakan media gambar berseri sudah dilaksanakan oleh guru sekaligus peneliti dengan runtut meskipun belum sempurna. Proses pembelajaran yang berlangsung dalam tiga siklus selalu mengalami peningkatan dari segi kuantitas maupun kualitas hasil tes dan aktivitas belajar siswa. Media gambar dari hasil obervasi menunjukkan membantu siswa dalam menungkan ide pertama mereka sebelum mengembangkan karangannnya. Hal ini sama halnya dengan penelitian yang dilakukan oleh Helda (2017) dan Oktovan dkk., (2020), bahwa media gambar berseri membantu siswa dalam menuangkan ide pertama sebelum mengembangkan karangannya menjadi karangan yang sempurna.

Secara terperinci pembahasan dari hasil penelitian pada setiap siklus dijabarkan sebagai berikut: Dengan meningkatnya nilai rata-rata dari siklus I hingga siklus III yaitu sebesar 65,33 pada siklus I, meningkat pada siklus II menjadi 72 dan pada siklus III meningkat menjadi 75,66. Oleh karena itu terjadi peningkatan nilai rata-rata pada siklus III, hal ini terlihat dan meningkatnya jumlah siswa yang mendapat nilai di atas KKM yaitu mencapai target diatas $70 \%$.

Tabel 3. Nilai Rata-Rata dan Persentase Hasil Tes Mengarang Setiap Siklus

\begin{tabular}{cccc}
\hline Siklus & $\begin{array}{c}\text { Nilai Rata- } \\
\text { Rata Kelas }\end{array}$ & $\begin{array}{c}\text { Persentase } \\
\text { Ketuntasan }\end{array}$ & Keterangan \\
\hline Kondisi Awal & 59,67 & $43,33 \%$ & Belum mencapai KKM \\
\hline Siklus I & 65,33 & $60 \%$ & Hasil belum maksimal \\
\hline Siklus II & 72 & $73,33 \%$ & Hasil sudah maksimal \\
\hline Siklus III & 75,66 & $86,66 \%$ & Hasil sudah lebih maksimal \\
\hline
\end{tabular}

Berdasarkan dari data tabel 3 di atas, pada setiap siklusnya terdapat peningkatan hasil rata-rata dan persentase ketuntasan belajar. Peningkatan dari setiap siklus dikarenakan adanya perencanaan. Perencanaan yang dilakukan oleh peneliti dilaksanakan pada setiap siklus. Perencanaan sangat penting untuk dibuat dalam menyusun rancangan tindakan, rancangan pembelajaran harus dilakukan bersama antara peneliti sekaligus guru yang akan melakukan tindakan dengan observer yang akan mengamati proses jalannya tindakan.

Tindakan yang dilakukan oleh guru sesuai dengan skenario pembelajaran yang telah dirancang. Dengan adanya skenario pembelajaran dilaksanakan dengan konsisten dan dapat meningkatkan kemampuan mengarang siswa. Observasi yang dilakukan oleh observer memberikan catatan-catatan kondisi nyata pada saat proses kegiatan belajar-mengajar berlangsung. Dari catatan itu digunakan sebagai bahan refleksi, jika terdapat masalah dari proses refleksi maka dilakukan proses pengkajian ulang, sehingga dengan adanya refleksi guru semakin memahami tentang 


\section{Netty Rismayanti}

Peningkatan Kemampuan Menulis melalui Media Gambar Berseri dalam Pembelajaran Bahasa Inggris pada Siswa Kelas VIII SMPN Kelapa 2 Kabupaten Tangerang

kekurangan dan kelebihan pada saat guru melakukan tindakan mengajar. Hal ini sesuai dengan teori Hopkins dalam Arikunto (2012:80) yaitu apabila terdapat masalah dari proses refleksi maka dilakukan proses pengkajian ulang melalui siklus berikutnya yang meliputi kegiatan perencanaan ulang, tindakan ulang, dan pengamatan ulang sehingga permasalahan dapat teratasi.

\section{Simpulan dan Saran}

Berdasarkan hasil penelitian dapat disimpulkan bahwa terjadi peningkatan kemampuan menulis karangan melalui media gambar berseri dalam pembelajaran bahasa Inggris pada siswa kelas VIII SMPN Kelapa 2 Kabupaten Tangerang. Peningkatan ini dibuktikan nilai rata-rata kelas pada siklus I yaitu 65,33 meningkat menjadi 72 pada siklus II, dan pada siklus III meningkat menjadi 75,66. Pembelajaran bahasa Inggris yang dilakukan peneliti pada siklus I hingga siklus III terjadi peningkatan setiap siklusnya, media gambar berseri yang digunakan peneliti pada pembelajaran bahasa Inggris dapat memperbaiki minat belajar siswa terhadap pembelajaran Bahasa Inggris dan membantu siswa dalam menuangkan ide awal dalam menulis karangan. Siswa juga tampak senang dan aktif dalam proses pembelajaran bahasa Inggris merupakan bukti perubahan yang positif.

Berdasarkan hasil penelitian ini, ada beberapa saran terutama pada guru bahasa Inggris hendaknya dapat menggunakan media gambar berseri sebagai media pembelajaran yang dapat meningkatkan kemampuan menulis siswa, serta dalam melaksanakan kegiatan belajar mengajar guru diharapkan dapat memberikan penguatan dengan menjelaskan materi dengan menarik agar semua siswa bisa terfokus dalam penjelasan guru yang menjadikan kegiatan belajar-mengajar berjalan dengan efektif dan lancar sesuai dengan apa yang diharapkan.

Kepala sekolah hendaknya juga selalu melakukan supervisi akademik dengan memantau proses pembelajaran di sekolah sehingga dapat mengetahui secara langsung dan pasti, mengenai pengelolaan kelas yang diterapkan oleh guru apakah sudah tepat atau belum. Dengan harapan jika ada kesalahan atau kekurangan dalam media pembelajaran dapat diperbaiki dan diberikan fasilitas untuk media pembelajaran yang mendukung kegiatan belajar mengajar di kelas.

Kemudian, untuk peneliti lanjutan karena penelitian ini baru sebatas meneliti penerapan media gambar berseri pada pembelajaran menulis bahasa Inggris dalam bentuk PTK sehingga peneliti lanjutan dapat menggunakan metode lain seperti eksperimen atau bisa menerapkan media gambar berseri khusus pada karangan deskripsi, eksposisi, persuasi, dan argumentasi atau jenis teks, seperti teks eksplanasi, teks laporan observasi, dan lainnya.

Silampari Bisa: Jurnal Penelitian Pendidikan Bahasa Indonesia, Daerah, dan Asing Vol. 4, No. 2, 2021 
Netty Rismayanti

Peningkatan Kemampuan Menulis melalui Media Gambar Berseri dalam Pembelajaran Bahasa

Inggris pada Siswa Kelas VIII SMPN Kelapa 2 Kabupaten Tangerang

\section{Daftar Pustaka}

Arikunto, S., dkk. (2012). Penelitian Tindakan Kelas. Jakarta: PT Bumi Aksara.

Arsyad, A. (2011). Media Pembelajaran. Jakarta: Rajawali Pers.

Brown, H-Douglas. (2000). Principles of Language Learning and Teaching. London: Longman.

Dardjowidjojo, S. (2014). Psikolinguistik Pengantar Pemahaman Bahasa Manusia. Jakarta: Pustaka Obor Indonesia.

Djamarah, S. B. \& Zain, A. (2010). Strategi Belajar Mengajar. Jakarta: Rineka Cipta.

Helda, T. (2017). Menulis Teks Cerita Pendek Berbantuan Media Gambar Berseri Siswa Kelas VII SMP Islam Khaira Ummah Padang. Gramatika STKIP PGRI Sumatera Barat, 3(2). doi:10.22202/jg.2017.v3i2.2186

Jauhari, H. (2013). Terampil Mengarang. Bandung: Nuansa Cendekia.

Khaerunisa. (2012). "Pengaruh Penggunaan Media Gambar Berseri terhadap Keterampilan Menulis Kreatif Puisi Siswa Kelas VII Mts. Islamiyah Ciputat Tahun Pelajaran 2011-2012". Fakultas IImu Pendidikan. Jakarta: Universitas Islam Negeri Syarif Hidayatullah.

Kusumah, W. \& Dwitagama, D. (2010). Mengenal Penelitian Tindakan Kelas. Jakarta: PT Indeks.

Nurdin. (2010). Dasar-Dasar Penulisan. Malang: UMM Press.

Oktovan, I. P., Riyadi, M., \& Masriah, M. (2020). Pengaruh Penggunaan Media Gambar dan Menulis Terpimpin terhadap Peningkatan Siswa dalam Keterampilan Menulis. EL-IBTIKAR: Jurnal Pendidikan Bahasa Arab, 9(1), 143. doi:10.24235/ibtikar.v9i1.6468

Rohami, A. (1997). Instructional Educative. Jakarta: Rineka Cipta.

Sadiman, A. S., dkk. (2010). Media Pendidikan. Jakarta: Rajawali Pers.

Sarudi, W. (2018). Penggunaan Media Kartu Gambar Berseri Untuk Meningkatkan Kemampuan Menulis Cerpen Siswa Kelas IX G SMPN 3 Wates Kediri. Hasta Wiyata, 1(1), 52-61. doi:10.21776/ub.hastawiyata.2018.001.01.06

Sulaeman, A. \& Goziyah. (2019). Metodologi Penelitian Pendidikan Bahasa dan Sastra. Edu Pustaka; Jakarta.

Sulaeman, A., \& Ariyana, A. (2018). Pengaruh Penggunaan Model Pembelajaran Examples Non-Examples terhadap Hasil Belajar Menulis Teks Berita pada

Silampari Bisa: Jurnal Penelitian Pendidikan Bahasa Indonesia, Daerah, dan Asing Vol. 4, No. 2, 2021 


\section{Netty Rismayanti}

Peningkatan Kemampuan Menulis melalui Media Gambar Berseri dalam Pembelajaran Bahasa Inggris pada Siswa Kelas VIII SMPN Kelapa 2 Kabupaten Tangerang

Siswa Kelas VIII SMPN 14 Kota Tangerang. Silampari Bisa: Jurnal Penelitian Pendidikan Bahasa Indonesia, Daerah, dan Asing, 1(2), 17-27. doi:10.31540/silamparibisa.v1i2.201

Tarigan H. G. (2008). Menulis sebagai Suatu Keterampilan Berbahasa. Bandung: Angkasa.

Tarigan, H. G. (2015). Berbicara sebagai Suatu Keterampilan Berbahasa. Bandung: Angkasa.

Widodo, G. (2021). Penggunaan Bahasa Ibu sebagai Alat Komunikasi Pengantar Bahasa Indonesia di Sekolah Dasar. Jurnal IImiah Edukasia, 1(1), 19-23. doi:10.26877/jie.v1i1.7960

Silampari Bisa: Jurnal Penelitian Pendidikan Bahasa Indonesia, Daerah, dan Asing Vol. 4, No. 2, 2021 